JAMP: Jurnal Adminitrasi dan Manajemen Pendidikan

Volume 4 Nomor 1 Maret 2021, Hal : 1 - 9

Tersedia Online di http://journal2.um.ac.id/index.php/jamp/

ISSN 2615-8574 (online)

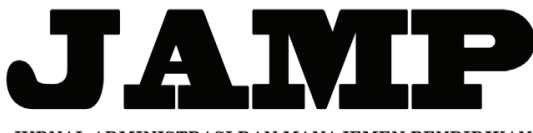

JURNAL ADMINISTRASI DAN MANAJEMEN PENDIDIKAN

\title{
PETA KAJIAN MANAJEMEN PENDIDIKAN DI INDONESIA
}

\author{
Fetty Ernawati \\ Muhammad Munadi
}

\author{
IAIN Surakarta -Jl. Pandawa Pucangan Kartasura \\ E-mail:muh.munadi@iain-surakarta.ac.id
}

\begin{abstract}
This study aims to map educational management studies in Indonesia, which includes the mapping of educational management studies in state and private colleges; as well as the comparison between the number of scientific journals and the number of educational management study programs from all levels of higher education in Indonesia. This study employed quantitative research methods and its data sources were originated from documents available on the website of Sinta Kemenristek/BRIN. The data were analyzed by employing descriptive statistics and explained by using descriptive narrations. The results show that there are 48 subjects of educational management studies in Indonesia and there are 299 authors who conduct studies on these subjects. These studies were published by 24 scientific journals. The subjects of educational management and Islamic educational management studies have the most sub-studies compared to other study subjects, including 12 sub-studies offered by these scientific journals. Moreover, there are 7 scientific journals owned by private Islamic colleges, 6 scientific journals owned by state colleges, 2 scientific journals owned by private colleges, and 1 scientific journals owned by a scientific community.
\end{abstract}

Keywords: Educational management; mapping scientific journals.

Abstrak: Penelitian ini bertujuan untuk memetakan kajian manajemen pendidikan di Indonesia, yang mencakup pemetaan kajian manajemen pendidikan di PTN dan PTS; serta perbandingan antara jumlah jurnal dengan jumlah program studi manajemen pendidikan dari semua jenjang pendidikan di Indonesia. Penelitian ini menggunakan metode penelitian kuantitatif dengan sumber data dari dokumen di website sinta Kemenristek/BRIN. Analisis data menggunakan statistik deskriptif, dan dijelaskan dengan menggunakan kualitatif deskriptif. Hasil penelitian menunjukkan subyek kajian manajemen pendidikan di Indonesia tercatat sejumlah 48 dan terdapat 299 orang penulis yang mengkajinya. Terwadahi dalam jurnal yang berjumlah 24 jurnal. Subyek kajian Education Management/Islamic Education Management juga paling banyak memiliki sub kajian dibandingkan subyek kajian lainnya yaitu memiliki 12 sub kajian yang ditawarkan oleh jurnal. Jurnal terbanyak dimiliki oleh PTKIN yaitu 8 jurnal dan PTKIS dengan 7 jurnal, selebihnya 6 jurnal dari PTN, 2 jurnal dari PTS dan 1 jurnal dari komunitas keilmuan.

Kata kunci: Peta kajian jurnal; manajemen pendidikan.

Program studi manajemen pendidikan atau administrasi pendidikan di Indonesia jumlahnya banyak. Data PDDikti menunjukkannya Perguruan Tinggi di Indonesia mempunyai 383 program studi (prodi) manajemen pendidikan dengan berbagai variasi penamaam program studi dari semua jenjang pendidikan. Ada 299 prodi S1, 63 prodi S2, dan 21 prodi S3. Prodi ini tersebar hampir di seluruh perguruan tinggi dari Sabang sampai Merauke. Diselenggarakan tidah hanya di bawah koordinasi Kementerian Pendidikan dan Kebudayaan (Kemendikbud) saja tetapi juga di bawah koordinasi Kementerian Agama (Kemenag). Prodi di bawah Kemenag memberikan tambahan nomenklatur sesuai afiliasi agama yang diakui pemerintah. Tabel 1 menunjukkan variasi penamaan prodi, jumlah dan jenjang program studi manajemen pendidikan. 
Tabel 1. Nama, Jumlah dan Jenjang Program Studi

\begin{tabular}{lcccc}
\hline \multirow{2}{*}{ Prodi } & \multicolumn{3}{c}{ Jenjang } & \multirow{2}{*}{ Jumlah } \\
\cline { 2 - 4 } & S3 & S2 & S1 & 315 \\
Manajemen Pendidikan Islam & 13 & 31 & 271 & 18 \\
Manajemen Pendidikan & 6 & 6 & 6 & 1 \\
Ilmu Manajemen Pendidikan & 1 & 0 & 0 & 44 \\
Administrasi Pendidikan & 1 & 22 & 21 & 3 \\
Magister Manajemen Pendidikan Tinggi & 0 & 3 & 0 & 2 \\
Manajemen Pendidikan Kristen & 0 & 1 & 1 & 383 \\
Jumlah & 21 & 63 & 299 & \\
\hline
\end{tabular}

Besarnya jumlah prodi semestinya berdampak pada kuatnya disiplin ilmu ini dengan ditunjang kegiatan tri dharma perguruan tinggi yang meliputi kegiatan pendidikan dan pengajaran, penelitian serta pengabdian kepada masyarakat. Kajian ilmu ini semestinya mengikuti perkembangan budaya. Hal ini mendasarkan pada pendapat Bharadwaj (Bharadwaj, 2010) bahwa Management is a product of culture, maka ilmu ini selalu uptodate sesuai perkembangan yang ada. Jika dikaitkan dengan globalisasi semestinya dari produk tri dharma PT maka prodi bisa menghasilkan alumninya seperti pernyataan AACSB International Globalization of Management Education Task Force (AACSB International, 2011) bahwa kompetensi dan kepercayaan diri lulusan yang lebih besar untuk melakukan bisnis dengan dampak global; lebih banyak wawasan penelitian tentang kompleksitas global para manajer, perusahaan, dan pasar yang diteliti; serta pelayanan yang lebih baik dari profesi manajemen global. Dengan mengikuti perkembangan menjadikan lembaga pendidikan perlu mengintensifkan praktik berdasarkan daya saing dan kinerja (Lee, Kwan, \& Li, 2020). Pernyataan tersebut menunjukkan bahwa istilah manajemen pendidikan merupakan konsep yang tumpang tindih, bersama dengan administrasi pendidikan dan kepemimpinan pendidikan. Ketiga konsep ini terkait tetapi tetap memiliki perbedaan definisi tergantung pada di mana istilah tersebut diterapkan (Lynch, 2020). Ketiga istilah tersebut memiliki kajian wilayah utama, sebagai berikut: Sumber daya manusia - siswa, tenaga pendidik, tenaga kependidikan, pemangku kepentingan serta masyarakat sebagai pengguna layanan pendidikan - sumber belajar meliputi media atau kurikulum serta fasilitas dan sumber daya keuangan, sebagai faktor pendukung yang membuat pendidikan berjalan dengan baik (Ali \& Abdalla, 2017).

Tumpang tindihnya tiga istilah di atas banyak ditemukan dalam riset-riset yang dilakukan para ahli. Temuan riset Gümüş, Bellibaş, Gümüş, \& Hallinger (2020) menunjukkan bahwa pemikiran para sarjana Manajemen dan Kepemimpinan Pendidikan Turki sebagian besar telah diterbitkan di jurnal berbasis Turki, ada peningkatan substansial dalam jumlah makalah yang diterbitkan dalam jurnal internasional dalam beberapa tahun terakhir. Literatur ini sebagian besar bersifat empiris dengan fokus topikal terkonsentrasi pada isu-isu seputar kepemimpinan sekolah dan perilaku organisasi. Riset lain yang dilakukan Tian \& Huber (2020) menunjukkan bahwa ada lima tema Manajemen dan Kepemimpinan Pendidikan (EdLAM), yaitu: kepemimpinan sekolah untuk meningkatkan prestasi akademik siswa dan efektivitas guru; kepemimpinan untuk perubahan pendidikan, akuntabilitas dan mempromosikan nilainilai demokrasi; kepemimpinan untuk keadilan sosial, equal education and narrowing achievement gaps; kepemimpinan instruksional kepala sekolah untuk peningkatan sekolah; dan kepemimpinan terdistribusi dan dampaknya terhadap iklim organisasi dan sikap serta stress guru. Konten EdLAM dari 2007 hingga 2016 lebih lanjut mengembangkan bidang penelitian berikut: dinamika antara pemimpin dan guru dalam pekerjaan kepemimpinan, risiko potensial kepemimpinan terdistribusi dan tantangan EdLAM pada Manajemen Publik Baru dan neoliberalisme.

Penelitian Wang \& Bowers (2016) menunjukkan bahwa hasil menonjol dari jurnal, interdisipliner, dan delapan cluster jurnal dalam jaringan kutipan menunjukkan bahwa administrasi pendidikan, sebagai bidang berpori, berinteraksi erat dengan sub-bidang pendidikan (misalnya pendidikan perkotaan dan pendidikan guru), disiplin ilmu lain (misalnya ekonomi, sumber daya manusia, sosiologi, dan psikologi), dan penelitian internasional. Selain jurnal sebagai sumber pengetahuan $(45,29$ persen), penulis juga menemukan buku (31,08 persen) dan laporan (14,98 persen) adalah sumber kutipan penting dalam 
literatur penelitian administrasi administrasi pendidikan. Buku-buku dan laporan yang paling banyak dikutip menjelaskan basis pengetahuan dalam teori, penelitian, dan praktik administrasi pendidikan.

Penelitian lain dari Hallinger \& Kovacevic (2019) menemukan bahwa basis pengetahuan Administrasi Pendidikan telah tumbuh secara dramatis sejak 1960 dengan percepatan laju pertumbuhan dan peningkatan keragaman gender dan geografis selama dua dekade terakhir. Selain itu teridentifikas empat aliran pemikiran utama yang telah muncul dari waktu ke waktu yang berfokus pada kepemimpinan untuk pembelajaran, kepemimpinan dan perubahan budaya, efektivitas sekolah dan peningkatan sekolah, dan guru-guru terkemuka. Ada pergeseran paradigma dari "administrasi sekolah" ke "kepemimpinan sekolah" selama enam dekade. Temuan penting lainnya mengidentifikasi "kepemimpinan untuk pembelajaran dan pengembangan siswa" sebagai "jangkar kognitif" dari struktur intelektual dari basis pengetahuan administrasi pendidikan.

Dosen-dosen manajemen pendidikan membutuhkan pemetaan kajian keilmuan yang jelas atas publikasi-publikasi ilmiah dalam jurnal, dalam rangka pengembangan keilmuan dan memenuhi tuntutan produktivitas dosen. Pemetaan tersebut juga mendorong pengelola jurnal untuk memperluas cakupan kajian keilmuan manajemen pendidikan.

\section{METODE}

Penelitian ini menggunakan metode penelitian kombinasi yang menggabungkan metode kuantitatif dan metode kualitatif. Jenis metode penelitian kombinasi yang dipakai adalah eksplanasi yaitu data-data kuantitatif dikumpulkan dan dianalisis terlebih dahulu, kemudian dilengkapi dengan data kualitatif. Data kualitatif menyediakan penjelasan lanjutan dari data kuantitatif yang dikumpulkan sejak awal. Sumber data dari dokumen di website sinta ristekbrin. Keabsahan data dilakukan dengan cara memvalidasi data yang berasal dari sinta ristekbrin ke data masing-masing jurnal melalui website online journal system. Analisis data menggunakan statistik deskriptif, dan dijelaskan dengan menggunakan kualitatif deskriptif. Analisis data menggunakan statistik deskriptif, dan dijelaskan dengan menggunakan kualitatif deskriptif. Data dipilah berdasar spesifikasi kajian, penamaan jurnal, ruang lingkup, peringkat sinta, dan penerbitnya. Setelah dipilah, kemudian dibuat prosentase dengan divalidasi pada website system jurnal online-nya.

\section{HASIL}

Pelacakan dari Ristekbrin menunjukan bahwa jumlah penulis jurnal berlatar belakang manajemen pendidikan ataupun administrasi pendidikan dapat dilihat pada Tabel 2.

\section{Tabel 2. Jumlah Penulis Sesuai Subyek Kajian}

\begin{tabular}{clc}
\hline No & \multicolumn{1}{c}{ Subyek } & Penulis \\
\hline 1 & Manajemen Pendidikan Islam & 240 \\
2 & Administrasi/Manajemen Pendidikan & 18 \\
3 & Manajemen Pendidikan Matematika & 5 \\
4 & Manajemen Pendidikan Tinggi & 6 \\
5 & Manajemen Pendidikan Dasar & 2 \\
6 & Ilmu Keagamaan Dan Manajemen Pendidikan & 1 \\
7 & Kepemimpinan Pendidikan Manajemen Pendidikan & 1 \\
8 & Konflik Dan Manajemen Pendidikan Islam & 1 \\
9 & Manajemen Pendidikan Anak Berkebutuhan Khusus & 1 \\
10 & Manajemen Pendidikan Dan Perpustakaan & 1 \\
11 & Manajemen Pendidikan Dan Teknologi Pembelajaran & 1 \\
12 & Manajemen Pendidikan Islam \& Pondok & 4 \\
13 & Manajemen Pendidikan Islam Anak Usia Dini & 1
\end{tabular}


14 Manajemen Pendidikan Kejuruan 1

15 Manajemen Pendidikan Nonformal 1

16 Manajemen Pendidikan Teknik 1

17 Manajemen Pendidikan Teknologi Kejuruan \& Fisika 1

18 Manajemen Pendidikan Telaah Kurikulum 1

19 Manajemen Pendidikan Theologi 1

20 Manajemen Pendidikan Vokasi 1

21 Manajemen Pendidikan/Dakwah 1

22 Manajemen Pendidikan/Kebijakan Pendidikan 1

23 Pendidikan Agama Islam \& Manajemen Pendidikan 4

24 Politik Hukum Islam Dan Manajemen Pendidikan Islam 1

25 Professor Manajemen Pendidikan IPA 1

26 Teknik Sipil dan Manajemen Pendidikan 1 $\begin{array}{ll}\text { Jumlah } & 299\end{array}$

Terdapat 26 subyek kajian yang telah dikaji oleh 299 penulis. Penulis paling banyak mengkaji tentang subyek kajian manajemen pendidikan Islam yaitu sejumlah 240 penulis. Selebihnya tersebar dalam subyek kajian lainnya, lihat Tabel 3.

Tabel 3. Jumlah Jurnal MP Sesuai Peringkat Indeksasi Sinta

\begin{tabular}{ccccccc}
\hline & \multicolumn{5}{c}{ Manajemen Pendidikan (MP) } & \multirow{2}{*}{ Jumlah } \\
\cline { 2 - 6 } & PTKIN & PTKIS & PTN & PTS & $\begin{array}{c}\text { Komunitas } \\
\text { Ilmiah }\end{array}$ & \\
\hline S1 & 0 & 0 & 0 & 0 & 0 & 0 \\
S2 & 0 & 0 & 0 & 0 & 0 & 0 \\
S3 & 0 & 0 & 3 & 1 & 0 & 4 \\
S4 & 0 & 0 & 0 & 1 & 0 & 1 \\
S5 & 0 & 0 & 2 & 0 & 1 & 3 \\
S6 & 0 & 0 & 0 & 0 & 0 & 0 \\
Jumlah & 0 & 0 & 5 & 2 & 1 & 8 \\
\hline
\end{tabular}

Jumlah jurnal manajemen pendidikan keseluruhan berjumlah 8 jurnal, yaitu 5 jurnal dari PTN; 2 jurnal dari PTS dan 1 jurnal dari komunitas ilmiah. Jurnal dengan nama Manajemen Pendidikan ada $32 \%$, lihat Tabel 4.

Tabel 4. Jumlah Jurnal MPI Sesuai Peringkat Indeksasi Sinta

\begin{tabular}{ccccccc}
\hline \multirow{2}{*}{ Sinta } & \multicolumn{5}{c}{ Manajemen Pendidikan Islam (MPI) } & \multirow{2}{*}{ Jumlah } \\
\cline { 2 - 5 } & PTKIN & PTKIS & PTN & PTS & $\begin{array}{c}\text { Komunitas } \\
\text { Ilmiah }\end{array}$ & \\
\hline S1 & 0 & 0 & 0 & 0 & 0 & 0 \\
S2 & 0 & 0 & 0 & 0 & 0 & 0 \\
S3 & 1 & 3 & 0 & 0 & 0 & 4 \\
S4 & 3 & 2 & 0 & 0 & 0 & 5 \\
S5 & 4 & 2 & 0 & 0 & 0 & 6 \\
S6 & 0 & 0 & 0 & 0 & 0 & 0 \\
Jumlah & 8 & 7 & 0 & 0 & 0 & 15 \\
\hline
\end{tabular}

Jumlah jurnal manajemen pendidikan Islam secara keseluruhan ada 15 jurnal, yaitu 8 jurnal dari PTKIN dan 7 jurnal dari PTKIS. Data ini menunjukkan bahwa jumlah jurnal yang menamai Manajemen Pendidikan Islam 60\%, lihat Tabel 5. 
Tabel 5. Jumlah Jurnal AP Sesuai Peringkat Indeksasi Sinta

\begin{tabular}{ccccccc}
\hline \multirow{2}{*}{ Sinta } & \multicolumn{5}{c}{ Administrasi Pendidikan (AP) } & \multirow{2}{*}{ Jumlah } \\
\cline { 2 - 6 } & PTKIN & PTKIS & PTN & PTS & $\begin{array}{c}\text { Komunitas } \\
\text { Ilmiah }\end{array}$ & \\
\hline S1 & 0 & 0 & 0 & 0 & 0 & 0 \\
S2 & 0 & 0 & 0 & 0 & 0 & 0 \\
S3 & 0 & 0 & 0 & 0 & 0 & 0 \\
S4 & 0 & 0 & 1 & 0 & 0 & 1 \\
S5 & 0 & 0 & 1 & 0 & 0 & 1 \\
S6 & 0 & 0 & 0 & 0 & 0 & 0 \\
Jumlah & 0 & 0 & 2 & 0 & 0 & 2 \\
\hline
\end{tabular}

Jurnal Administrasi Pendidikan berjumlah 2 jurnal, dan kesemuanya dari PTN (terindeks sinta 4 dan sinta 5). Hanya 8\% jurnal dengan nama Administrasi Pendidikan. Berdasarkan penelusuran data diperoleh juga perbandingan cakupan kajian jurnal dengan cakupan teoritik keilmuan adiministrasi pendidikan atau manajemen pendidikan yang ditawarkan oleh jurnal yaitu pada Tabel 6 .

Tabel 6. Jumlah Sub Kajian Jurnal Manajemen Pendidikan

\begin{tabular}{|c|c|c|}
\hline No & Sub Kajian & Jumlah \\
\hline 1 & Educational Leadership & 15 \\
\hline 2 & Educational Economics & 7 \\
\hline 4 & Educational Politics & 6 \\
\hline 5 & Education Management/Islamic Education Management & 22 \\
\hline 6 & School Management & 23 \\
\hline 7 & Human Resource Management & 10 \\
\hline 8 & Education Development & 11 \\
\hline 9 & Management in Higher Education & 2 \\
\hline 10 & Strategic Management & 6 \\
\hline
\end{tabular}

Tabel 6 menunjukkan bahwa cakupan manajemen pendidikan spesifikasi kajian School Management paling banyak memiliki sub kajian yaitu 23 sub kajian yang ditawarkan oleh jurnal, Education Management/Islamic Education Management memiliki 22 sub kajian, Educational Leadership memiliki 15 sub kajian, Education Development memiliki 11 sub kajian, Human Resources Management memiliki 10 sub kajian, Educational Economics memiliki 7 sub kajian, Educational Politics dan Strategic Management masing-masing memiliki 6 sub kajian, dan Management in Higher Education memiliki 2 sub kajian.

\section{PEMBAHASAN}

Terdapat 383 prodi manajemen pendidikan dari semua jenjang pendidikan dengan variasi penamaannya. Jika setiap prodi mempunyai 5 dosen homebase seperti yang dipersyaratkan, dan setiap dosen minimal menulis 1 artikel penelitian per tahun maka setiap tahunnya minimal akan ada 1915 artikel penelitian. Jika dalam setiap terbitan sekurang-kurangnya 5 artikel dan terbit minimal 2 kali dalam setahun seperti yang dipersyaratkan dalam akreditasi terbitan berkala ilmiah, maka sebenarnya akan butuh sekitar 190 jurnal (jika setiap terbit ada 5 artikel) atau 95 jurnal (jika setiap terbit ada 10 artikel) untuk menampung semua tulisan dosen-dosen manajemen pendidikan di Indonesia. Realitanya jumlah keseluruhan jurnal manajemen pendidikan di Indonesia, baik jurnal MP, AP maupun MPI (lihat tabel 3, 4, 5) adalah 25 jurnal (PTKIN 8 jurnal, PTKIS 7 jurnal, PTN 7 jurnal, PTS 2 jurnal dan Komunitas ilmiah 1 jurnal). Jumlah tersebut tentu sangatlah kurang memadai untuk menampung artikelartikel ilmiah para dosen manajemen pendidikan.

Hanya ada 299 penulis dari perkiraan jumlah dosen homebase manajemen pendidikan yang berjumlah 1915 orang atau sebesar 15,6\% saja yang menulis dalam jurnal manajemen pendidikan. 
Realita tersebut menunjukkan bahwa tuntutan produktivitas dosen dalam menulis pada jurnal ilmiah belum terpenuhi atau dengan kata lain produktivitas dosen manajemen pendidikan di Indonesia dalam menulis artikel ilmiah masih rendah.

Jumlah penulis sesuai subjek kajiannya (lihat tabel 2), dari 299 penulis pada 26 subyek kajian tersebut ternyata 240 penulis diantaranya atau $80,27 \%$ mengkaji tentang manajemen pendidikan Islam. Dan sisanya menyebar pada 25 subyek kajian lainnya. Data tersebut menunjukkan bahwa belum semua subyek kajian manajemen pendidikan dikaji oleh para penulis. Peluang menulis dalam jurnal manajemen pendidikan masih terbuka luas untuk subyek kajian di luar subyek kajian manajemen pendidikan Islam. Data tersebut juga menunjukkan bahwa pengembangan kajian keilmuan manajemen pendidikan belum menjangkau seluruh cakupan manajemen pendidikan.

Pengelola jurnal manajemen pendidikan yang menawarkan subyek kajian di luar subyek kajian manajemen pendidikan Islam pun kurang mendapatkan artikel ilmiah dari para penulis, sehingga untuk mempertahankan terbitan berkalanya juga mengalami kesulitan. Kondisi yang seperti ini tentu saja tidak diinginkan oleh seluruh pengelola jurnal. Kesulitan pengelola jurnal dalam mempertahankan terbitan berkala juga berpengaruh pada pencapaian akreditasi jurnalnya.

Jurnal manajemen pendidikan, administrasi pendidikan dan manajemen pendidikan Islam yang berjumlah 24 (lihat tabel 3,4,5), rata-rata memiliki peringkat indeksasi Sinta 3, Sinta 4 dan Sinta 5. Belum ada satu pun mendapat peringkat Sinta 1 maupun Sinta 2. Kondisi ini butuh perhatian dalam rangka meningkatkan kualitas jurnal dan kualitas tulisan atau artikel ilmiah, dan upaya serius agar tidak ada penurunan kualitas dikarenakan pengelola jurnal tidak bisa mempertahankan terbitan berkalanya yang disebabkan kurangnya jumlah tulisan artikel ilmiah. Atau karena adanya kendala kurangnya tulisan artikel ilmiah yang masuk ke pengelola, kemudian memaksa pengelola untuk memperluas subyek kajiannya. Subyek kajian dan penamaan jurnal yang kurang spesifik berakibat pada penilaian jurnal yang kurang optimal pula. Penggerak produksi pengetahuan manajemen/administrasi pendidikan masih terbatas pada perguruan tinggi sementara asosiasi profesi belum kuat dalam konteks ini. Namun ketika dikonfirmasi pada satu jurnal ditemukan ada kerjasama antar program studi pada perguruan tinggi (Perkumpulan Program Studi Manajemen Pendidikan Islam) dalam menerbitkan jurnal, yaitu Jurnal Tadbir: Jurnal Studi Manajemen Pendidikan. Disamping itu rata-rata penerbit produksi pengetahuan masih didominasi oleh kelembagaan perguruan tinggi hampir 24 jurnal, sedangkan komunitas ilmiah hanya 1 jurnal, yaitu Jurnal Diklat Review.

Tabel 6 menunjukkan bahwa jumlah sub kajian pada setiap kajian manajemen pendidikan sangatlah beragam dan paling banyak memiliki sub kajian adalah kajian Education Management/Islamic Education Management yaitu 12 sub kajian dan kajian Educational Leadership sebanyak 10 sub kajian. Peluang pengembangan dan penambahan jurnal manajemen pendidikan dan administrasi pendidikan masih terbuka luas, mengingat bahwa jurnal yang berkualitas adalah jurnal yang secara spesifik atau super spesifik memuat artikel-artikel ilmiah pada kajian ilmu tertentu. Jurnal dipakai sebagai ajang untuk mempublikasikan hasil penelitian pada kajian keilmuan tertentu (spesifik) dan dalam rangka pengembangan keilmuan tersebut. Sedikit kontraproduktif dengan hasil penelitian Maftukhin (2015), yaitu bahwa salah satu strategi yang bisa dipakai dalam pengembangan ilmu pengetahuan adalah dengan relasi antar ilmu yang berarti mempersyaratkan adanya keluasan cakupan keilmuan.

Penelitian lain yang senada dengan penelitian Maftukhin adalah penelitian Wang \& Bowers (2016) menunjukkan bahwa administrasi pendidikan, sebagai bidang berpori, berinteraksi erat dengan subbidang pendidikan (misalnya pendidikan perkotaan dan pendidikan guru), disiplin ilmu lain (misalnya ekonomi, sumber daya manusia, sosiologi, dan psikologi), dan penelitian internasional. Penelitian manajemen pendidikan berpori bisa menghasilkan produk publikasi ilmiah yang sesuai dengan tuntutan jaman, minimal bisa menjawab tuntutan produk penelitian yang mengacu pada kerangka technological readiness level dan market readiness level.Kedua penelitian tersebut menunjukkan bahwa pengembangan kajian keilmuan manajemen pendidikan membutuhkan interaksi dengan cakupan kajian-kajian keilmuan lainnya. Jika sebuah jurnal mempersyaratkan kajian keilmuan spesifik bersifat interdisipliner dan multidispliner, maka artikel-artikel jurnal untuk pengembangan keilmuan manajemen pendidikan 
yang monodisipliner banyak yang tidak termuat atau tertolak dalam jurnal manajemen pendidikan atau administrasi pendidikan.

Tuntutan produktivitas dosen dan mahasiswa dalam mempublikasikan karya ilmiah di jurnal sudah seharusnya diikuti oleh ketersediaan jumlah jurnal yang sesuai dengan cakupan ilmu yang dimiliki. Cakupan kajian ilmu manajemen pendidikan sangatlah luas dan jumlah prodi yang harus terwadahi publikasinya dalam jurnal juga sangatlah banyak. Realitanya, perbandingan jumlah jurnal manajemen pendidikan dengan banyaknya prodi manajemen pendidikan dari semua jenjang pendidikan belumlah ideal. Cakupan keilmuan manajemen pendidikan dengan realita cakupan jurnal juga terlihat belum ideal. Pemetaan cakupan keilmuan manajemen pendidikan dan cakupan jurnal ilmiah dibutuhkan untuk menentukan peningkatan dan pengembangan jurnal, baik secara kuantitas maupun kualitas.

Jumlah penulis pada subyek kajian manajemen pendidikan Islam tercatat paling banyak yaitu 232 penulis, namun jika dibandingkan dengan jumlah jurnal manajemen pendidikan Islam yang berjumlah 15 itu pun perbandingannya juga masih belum ideal. Penulis Indonesia lebih banyak fokus pada subyek kajian manajemen pendidikan Islam dibandingkan fokus pada subyek kajian yang lain. Kondisi ini berpengaruh pada jumlah jurnal manajemen pendidikan Islam dari PTKIN secara supply dan demand.

Terfokusnya penulis pada salah satu subyek kajian manajemen pendidikan juga berpengaruh pada pengembangan keilmuan dari manajemen pendidikan, karena penelitian-penelitian dan kajian tidak dilakukan secara merata pada semua subyek kajian. Pengembangan ilmu manajemen pendidikan membutuhkan banyak data dari hasil penelitian dan kajian mendalam dari para peneliti di bidang manajemen pendidikan.

Perbandingan jumlah jurnal dengan jumlah keseluruhan program studi manajemen pendidikan dari semua jenjang pendidikan di Indonesia adalah 24:383 atau dengan kata lain 1 jurnal mewadahi tulisan dari 16 prodi untuk dipublikasikan. Perbandingan tersebut kurang ideal, karena jumlah jurnal tidak sebanding dengan banyaknya publikasi prodi yang harus dilayani dan cakupan keilmuan manajemen pendidikan yang luas.

Penulisan artikel ilmiah melalui jurnal ilmiah merupakan bentuk produksi pengetahuan. Hal ini ditegaskan The All European Academies (ALLEA) (The All European Academies, 2019) dengan pernyataan bahwa ada dua alasan penting berkaitan dengan produksi pengatahuan yaitu (1) Trust within scientific research encourages the comfort and confidence among researchers needed to share results and rely on each other's work and methods; (2) Trust in the practice and production of science is socially relevant for resolving public controversies and enhancing a comfortable general acceptance of scientific results. Pendapat ini menunjukkan bahwa produksi pengetahuan dengan diawali penelitian yang berlanjut pada publikasi hasil riset setidaknya mengandung 2 unsur, yaitu: kepercayaan dalam penelitian ilmiah mendorong kenyamanan dan kepercayaan di antara para peneliti yang diperlukan untuk berbagi hasil dan bergantung pada masing-masing pekerjaan dan metode orang lain; serta kepercayaan pada praktik dan produksi sains relevan secara sosial untuk menyelesaikan kontroversi publik dan meningkatkan penerimaan umum yang nyaman atas hasil ilmiah. Temuan ini menunjukkan bahwa masih publikasi ilmiah baru sebatas gerakan akses terbuka pada jurnal dari beragam ruang lingkup tulisan di jurnal serta belum adanya penulis diantara 2 PT berbeda kementerian yang mengembangkan keilmuan. Disinilah diperlukan mengimplementasikan usulan Czerniewicz (2013) bahwa perlu ada gerakan dari akses ke pengetahuan menuju ke partisipasi penuh dalam penciptaan pengetahuan dan dalam komunikasi ilmiah pada semua ilmuwan manajemen/administrasi pendidikan.

\section{SIMPULAN}

Tuntutan produktivitas dosen manajemen pendidikan dalam mempublikasikan karya ilmiah belum terpenuhi, dikarenakan kurangnya ketersediaan jumlah jurnal yang sesuai dengan cakupan ilmu yang dimiliki dan masih sedikitnya jumlah penulis yang mempublikasikan karya ilmiahnya dalam jurnal manajemen pendidikan. Kondisi seperti ini memberikan peluang besar pengembangan dan penambahan jumlah jurnal manajemen pendidikan dan jika peluang ini digunakan oleh perguruan tinggi baik 
PTN, PTS, PTKIN, PTKIS dan asosiasi prodi, maka akan ada peluang besar juga bagi penulis untuk mempublikasikan karya ilmiahnya. Pengembangan kajian keilmuan manajemen pendidikan belum menjangkau seluruh cakupan keilmuan manajemen pendidikan. Pengembangan kajian keilmuan manajemen pendidikan juga membutuhkan interaksi dengan cakupan kajian keilmuan lainnya agar cakupan keilmuannya meluas.

Penelitian ini telah memetakan kajian manajemen pendidikan di Indonesia, yang mencakup pemetaan kajian manajemen pendidikan di PTN dan PTS; pemetaan di PTN dan PTKIN; pemetaan di PTN, PTS, PTKIN, PTKIS; serta perbandingan antara jumlah jurnal dengan jumlah program studi manajemen pendidikan dari semua jenjang pendidikan di Indonesia, namun belum mengkorelasikannya dengan pengembangan keilmuan manajemen pendidikan. Penelitian ini juga membutuhkan penelitian lanjutan terkait dengan perbedaan fokus kajian di masing-masing perguruan tinggi baik PTKIN, PTKIS, PTN, PTS dan komunitas keilmuan. Peneliti selanjutnya diharapkan bisa melengkapinya, sehingga pemetaan ini bermanfaat pada pengembangan keilmuan manajemen pendidikan dan pengembangan jurnal manajemen pendidikan di Indonesia.

Hasil penelitian juga menunjukkan bahwa penggerak produksi pengetahuan didominasi oleh Perguruan Tinggi, sementara kontribusi dari asosiasi profesi atau komunitas keilmuan belum kuat yaitu baru ada satu jurnal saja yang berasal dari komunitas keilmuan yaitu Jurnal Diklat Review. Hasil penelitian tersebut menunjukkan bahwa masih dibutuhkan adanya kajian penelitian mendalam tentang faktor-faktor penyebab kurang kuatnya kontribusi dari asosiasi profesi atau komunitas keilmuan dalam produksi pengetahuan.

\section{DAFTAR RUJUKAN}

AACSB International. (2011). Globalization Of Management Education: Changing International Structures, Adaptive Strategies, and the Impact on Institutions. Bingley: Emerald Group Publishing Limited. Retrieved February 12, 2020, from https://www.aacsb.edu/-/media/aacsb/publications/research-reports/aacsbglobalization-of-management-education-task-force-report-2011.ashx?la=en

Ali, I. A., \& Abdalla, M. S. (2017). Educational Management, Educational Administration and Educational Leadership: Definitions and General concepts. SAS Journal of Medicine (SASJM) , 3(12), 326-329. Retrieved March 12, 2020, from http://saspjournals.com/wp-content/uploads

Bharadwaj, A. (2010). Globalization in Management Education: Challenges and Strategies. International Journal of Arts and Sciences, 3(7), 466-477. Retrieved February 12, 2020, from http://www.openaccesslibrary.org/ images/RLN196_Apoorva_Bharadwaj.pdf

Czerniewicz,L. (2013, Sepetember 14). Confronting global knowledge production inequities. University World News . Retrieved May 12, 2020, from https://www.universityworldnews.com/post.php?story=20130913161503686

Gümüş, S., Bellibaş, M., Gümüş, E., \& Hallinger, P. (2020). Science mapping research on educational leadership and management in Turkey: a bibliometric review of international publications. School Leadership \& Management Formerly School Organisation, 40(1). Retrieved February 12, 2020, from 10.1080/13632434.2019.1578737

Hallinger, P., \& Kovacevic, J. (2019, June). A Bibliometric Review of Research on Educational Administration: Science Mapping the Literature, 1960 to 2018. Review of Educational Research, 89(3), 335-369. doi: $10.3102 / 0034654319830380$

Lee, T. L., Kwan, P., \& Li, B. Y. (2020). Neoliberal challenges in context: a case of Hong Kong. International Journal of Educational Management, 34(4), 641-652. doi:10.1108/IJEM-06-2019-0220

Lynch, R. A.-o. (2020). Educational Management. In O. U. Press, Oxford Research Encyclopedia of Education. doi:10.1093/acrefore/9780190264093.013.701

Maftukhin. (2015). Ilmuwan, Etika dan Strategi Pengembangan Ilmu Pengetahuan di Indonesia. Episteme, 10(1). doi:https://doi.org/10.21274/epis.2015.10.1.199-226

Munadi, M. (2020). Manajemen Pendidikan Tinggi di Era Revolusi Industri 4.0. Jakarta: Kencana Prenada Media. Retrieved April 20, 2020, from https://books.google.co.id/books?id=1pLyDwAAQBAJ\&pg=PA34\&dq=ma rket + readiness + level + dan + muhammad + munadi $\& h l=e n \& s a=X \& v e d=2 a h U K E w j V n s v B o J b t A h W 6 I L c A H W$ 9jAz0Q6AEwAHoECAUQAg\#v=onepage\&q=market\%20readiness\%20level\%20dan\%20muhammad\%20 munadi\&f=false 
The All European Academies. (2019). Trust Within Science: Dynamics and Norms of Knowledge Production. ALLEA,. Retrieved May 12, 2020, from https://www.allea.org/wp-content/uploads/2019/01/ALLEA_ Discussion_Paper_2.pdf

Tian, M., \& Huber, S. (2020). Mapping educational leadership, administration and management research 20072016 Thematic strands and the changing landscape. Journal of Educational Administration, 58(2), 129-150. doi:10.1108/JEA-12-2018-0234

Wang, Y., \& Bowers, A. J. (2016). Mapping the field of educational administration research: a journal citation network analysis. Educational Policy Studies Faculty Publications, 22. Retrieved March 11, 2020, from https://scholarworks.gsu.edu/eps_facpub/22 